\title{
Childhood sexual abuse and adult binge drinking among Kanak women in New
}

\section{Caledonia}

Christine Hamelin, Christine Salomon, Rémi Sitta, Alice Guéguen, Diane Cyr, France Lert Inserm (National Institute of Health and Medical Research), Unit 687, Villejuif, France e-mail address corresponding author: Christine.hamelin@inserm.fr

\begin{abstract}
The long term consequences of violence against women are poorly documented within the context of political domination, economic inequalities and rapid social change of indigenous communities. Using data from the first population study on violence against women and their consequences on health in New Caledonia, this article investigates the association between childhood sexual abuse and binge drinking among adult Kanak women. Face-to-face standardised interviews were conducted in 2002-2003, among women aged 18-54 years drawn from the electoral rolls $(\mathrm{n}=$ 441). Childhood sexual abuse before 15 years of age was reported by $11.6 \%$ of respondents. Nearly all the perpetrators $(96 \%)$ were known to the victims $(63 \%$ being a close relative). The rate of frequent binge drinking within the last 12 months was 34\%. After controlling for social and demographic factors an independent association was found between childhood sexual abuse and binge drinking (OR $=1.95,95 \%$ CI: $1.02-3.74$ ). This study is the first to analyse the contribution of childhood sexual abuse to the likelihood of later heavy alcohol use in an indigenous population in the South Pacific. The findings call for improving and giving priority to care for children who are victims of violence to prevent long-term consequences and to develop prevention programs aimed at alcohol-related behaviour in women, while taking into account simultaneous individual and collective factors.
\end{abstract}

\section{Introduction}


In the countries of the Pacific, studies on violence against women report high rates of childhood sexual abuse against girls, especially in indigenous communities (Anderson \& Wild, 2007 ; Australian Bureau of Statistics, 2006; Fanslow, Robinson, Crengle, \& Perese, 2007 ; Stanley, Kovacs, Tomison, \& Cripps, 2002). The consequences of such violence for adult women, which are well documented in industrialised countries, remain to be understood within the specific context of political domination, economic inequalities, and rapid social change of these indigenous communities. Using data from a study on violence against women in New Caledonia (southwestern Pacific), this paper focuses on the association between early sexual violence and adult heavy alcohol use in indigenous Kanak women.

Heavy alcohol use is a common feature of many indigenous communities, although the severity of the problem varies within as well as between groups (Kunitz, 2006). Among Kanaks in New Caledonia, until recently, male drunkenness was accepted, and aggressive or transgressive behaviour when drunk was excused as a state of temporary dementia (Salomon, 2000a). Although female alcohol abuse remains socially stigmatised, recent ethnographic observations show that drunkenness has become more common and more visible among young Kanak women during festivities (Bensa \& Salomon, 2003). Actually, the number of female arrests for drunkenness in public places has increased: from January to June 2003, the proportion of women in jail registers of the central police station in Nouméa reached $8 \%$ for the first time, a marked increase over previous years (Direction des Affaires Sanitaires et Sociales, 2003). Similar to Australia's Aboriginal population (Saggers \& Gray, 1998; Shore \& Spicer, 2004) and to Maoris of New Zealand (Huakau, Asiasiga, Ford, Pledger, Casswell, Suaalii-Sauni et al., 2005), in the Kanak community of New Caledonia, alcohol is consumed occasionally and in large quantities, leading to intoxication. Overall, there are numerous binge drinkers, a small proportion of moderate drinkers and a large proportion of abstainers. The rate of drinkers doubles during the weekend, and the quantity of alcohol consumed quadruples. Among weekend drinkers, who account for $21 \%$ of all drinkers and who are characterised by 'binge' consumption of large quantities of alcohol, the Kanaks appear to be over-represented (Institut Louis Harris, 2003). 
In the past 20 years, a growing body of literature has focused on the association between female alcohol abuse and the experience of violence. Several studies show the role of sexual abuse during childhood in future alcohol abuse (Bensley, Eenwyk, \& Simmons, 2000; Dube, Anda, Felitti, Edwards, \& Croft, 2002; Jasinski, Williams, \& Siegel, 2000). Although the pathways underlying this association remain incompletely understood, these findings are consistent with the theory that a personal history of sexual abuse at a young age is associated with subsequent drinking problems, at least in women; studies of men are fewer, and their findings less convergent (Langeland \& Hartgers, 1998; Simpson \& Miller, 2002). Little research has addressed this association in indigenous communities, and current findings are not consistent. Whereas some studies revealed no association between sexual abuse and indicators of excessive alcohol use in adulthood (Kunitz, Levy, McCloskey, \& Gabriel, 1998; Libby, Orton, Novins, Spicer, Buchwald, Beals et al., 2004), others do document a significant association, suggesting that childhood sexual abuse increases the likelihood of alcohol misuse in adulthood (Koss, Yuan, Dightman, Prince, Polacca, Sanderson et al., 2003; Robin, Chester, Rasmussen, Jaranson, \& Goldman, 1997).

Interpersonal and gender violence is a matter of concern in the Kanak community. Kanak women are exposed to high levels of violence, especially sexual violence: $14 \%$ report sexual violence from their intimate partner within the last 12 months, compared to $2.6 \%$ in other groups living in New Caledonia. Among Kanak women aged 18 to 24 years, 12\% report a sexual assault from an acquaintance (other than an intimate partner), while the proportion is $5.2 \%$ among non-Kanak women (Salomon \& Hamelin, 2008). Few quantitative data are available regarding childhood sexual abuse, and none of them refer to ethnicity. Among men sentenced to jail, 15.9\% were sentenced for violence against adults or minors, and $39 \%$ were sentenced for rape or other forms of sexual assault (Guillonneau \& Kensey 1999). In 2002, in a total population of 200000,200 sexual assaults and rapes of minors were reported to law enforcement officials (Les Nouvelles Calédoniennes July1, 2003). The same year, two-thirds of the victims seeking help from "SOS Sexual Violence," an association that helps victims of violence, were minors (Les Nouvelles Calédoniennes July 1, 2003).

An analysis of the association between violence and alcohol can not be performed without considering the social context, which is known to be determinant in levels and patterns of alcohol use 
(Day \& Homish, 2002 ; Kunitz, 2006). Although New Caledonia has long been a French settlement colony, the Kanaks have remained the dominant population group: $44 \%$ of the 230000 inhabitants of the Caledonian Archipelago are Kanak, 34\% are European, 12\% are Polynesian, 5\% are Asian and 5\% are Other (Institut Territorial de la Statistique et des Etudes Economiques, 2001). But, like indigenous people in Australia, New Zealand, Canada and the United States, they have experienced colonial land conquest, massive conversion to Christianity, limitation of their rights, forced relocation and mandatory work for settlers (Merle, 1995; Naepels \& Salomon, 2007). Political domination, persistent economic inequalities, institutionalised racism, and difficulties in coping with rapid social and cultural change may explain the high level of alcohol abuse in the Kanak community as in other indigenous communities (Beauvais, 1998; Brady, 2000; Brady \& Palmer, 1984; Cactano, Clark, \& Tam, 1998; Roy, 2005).

Today, however, the Kanak community appears more and more socially differentiated. In the 1980s, nationalist rebellion for independence forced political concessions from France. In addition to political arrangements, the agreements signed between the French Government and independent parties promoted better access to education and employment for the Kanaks (Matignon Accord, 1989; Nouméa Accord, 1998). Subsequent changes have not been sufficient to rectify huge inequalities related to colonisation, but the Kanak community has become more socially and culturally heterogeneous. Although the Kanaks continue to live mostly in the rural areas of the Loyalty Islands and on the main island, more Kanaks are now living in Greater Nouméa, the only real urban zone (Hamelin, 2000). Disparity in economic resources between rural and urban populations has been increasing since the nickel boom between 1972 and 1986 leading to the development of paid work and a general monetisation of subsistence (Bensa \& Freyss, 1994; Djama, 1999). As well, women have joined the labour market, mostly as low grade employees (cleaning staff, domestic work, low grade civil servants), and, in rural areas, they participate in the informal economy mainly the sale of agricultural products. Despite enduring inequalities, the level of education is increasing among the new Kanak generations, and it has contributed to the progressive emergence of a Kanak urban middle class (Hamelin \& Wittersheim, 2002). 
In the last 20 years, the religious divide inherited from massive forced conversion to Christianity by Catholic or Protestant missionaries during the first half of the 20th century (Naepels \& Salomon, 2007), has been made more complex by successful proselytising by new Christian churches (Jehovah's Witnesses, Pentecostals, Seventh-day Adventists). Along with population mixing, mainly in Greater Nouméa, these changes question ancient intergenerational and gender norms. Community and family-based forms of solidarity, male domination and gender-based division of tasks and activities now co-exist with more individualistic behaviour and a claim for gender and age equality. The preference expressed by young Kanak women for single life rather than for marriage is an example of this trend (Salomon, 1998).

Such an important and rapid social change may influence Kanak women's alcohol consumption. Social and demographics characteristics, including age, marital status, peer sociability, education and income level have been described as risk factors for women's binge drinking in industrialised countries (Day \& Homish, 2002; Karlamangla, Zhou, Reuben, Greendale, \& Moor, 2006; Kuntsche, Rehm, \& Gmel, 2004) and in indigenous communities (Ames \& Rebhun, 1996; Collins \& McNair, 2002). Studies among American indigenous communities indicate that community affiliation (either measured by place of residence or cultural identification) can be also associated with alcohol abuse (Kunitz, Gabriel, Levy, Henderson, Lampert, McCloskey et al., 1999; May \& Gossage, 2001). Although research findings in this area are heterogeneous and vary across countries, they highlight the importance of social characteristics in predicting alcohol use. Using data from the first population study on violence against women and their consequences on health in New Caledonia, this paper focuses on the contribution of childhood sexual abuse to binge drinking among Kanak women. The present analysis takes into account demographic and social factors.

\section{Methods}

\section{Participants/Sample}

We used data from a general population survey conducted in New Caledonia from November 2002 to August 2003, among women aged 18-54. The sample was drawn from the electoral rolls 
where most New Caledonian women are registered (88.2\% in 2002 for this age group) due to the political issues associated with self-determination. Sampling from electoral rolls is stratified by age to better reflect the age structure of the New Caledonian population. The sampling method resulted in all subjects having an equal weight of 1 . To be sure that we questioned around 1,000 participants, we drew an age-stratified sample of 4,000 women at random. These 4,000 subjects served as a pool from which women were drawn in successive waves to be contacted, until the desired number of interviewees was reached. In all, 1,679 women were drawn from the pool of 4,000 for interviewers to contact. A letter describing the survey as a study on the living conditions and security of New Caledonian women was sent to these women, advising them that they were going to be contacted by an interviewer (by telephone or at home) and informing them of their right to decline the opportunity to take part, to subsequently change their mind before or during the interview, and their right to access and rectify the data.. Of those 1679 women, 580 could not be located or had moved outside the area of residence registered on the electoral rolls due to studies away from home, marriage, entering the work force, or simply moving to Nouméa to escape family constraints (Naepels, 2000). One thousand ninety-nine women were successfully contacted, and 1,012 (92.1\%) agreed to participate. Of the women who did not participate, $5 \%$ refused to take part, and $2.9 \%$ missed their appointments. Respondents who discontinued the interview (less than 1\%) did so for personal reasons, and all incomplete interviews were interrupted before the questions on violence were asked. In all, 1,012 took part in the survey. Among them, only Kanak women $(n=441)$ were included in the present analyses.

\section{Questionnaire}

Data were collected using a standardised questionnaire in face-to-face interviews that lasted one hour on average. Although the interviewer knew the identity of the women to contact them for the interview, this information was not recorded on the questionnaire forms to preserve anonymity. The first part of the questionnaire contained information about the women's social and demographic characteristics. Ethnic classification was based on self-definition, according to the $1996 \mathrm{New}$ Caledonia Census. Questions about the women's present and past family life included those asking about growing up with a parent who had alcohol problems. The second part concerned women's health 
and their use of psychoactive substances, including alcoholic beverages, during the preceding 12 months. To reduce the likelihood of under-reporting of childhood sexual violence, and to promote the recollection of the oldest memories, questions on violence were purposely included at the end of the questionnaire after questions on physical, sexual, verbal and psychological violence experienced in the preceding 12 months had been asked. This also allowed some degree of confidence to be established between the interviewer and the interviewee before the more sensitive questions were asked. This study complied with the ethical guidelines for confidentiality formulated by the World Health Organisation (Watts, Heise, Ellsberg, \& Garcia-Moreno, 2001).

\section{Variables of interest}

Childhood sexual abuse was assessed using two questions about lifetime sexual abuse: "During your life, has anyone ever fondled you sexually when you did not want to, or unsuccessfully tried to have sexual intercourse with you?" and "During your life, has anyone ever forced you to have sexual intercourse against your will?" In both cases, women were asked their age at the time of the event or at the first and last times when repeated abuse was reported. Thus, the indicator of childhood sexual abuse is defined as having experienced sexual fondling, attempted rape or rape one or more times before 15 years of age.

Alcohol consumption was documented at the end of the health section of the questionnaire, before the questions on violence were posed. This information covered the type and quantity of alcohol, and the frequency and circumstances of drinking. Binge drinking was defined as drinking six standard glasses (a standard drink $=10$ grams of ethyl alcohol) of alcohol or more on a single occasion at least six times during the year preceding the survey. Abstinent women and alcohol drinkers not meeting the definition of binge drinking were grouped together. This indicator of alcohol misuse is based on alcohol-use profiles proposed in the Health and Social Protection Survey (Institut de Recherche et Documentation en Economie de la Santé, 2005) and INSEE's health survey (Direction de la Recherche des Etudes de l'Evaluation et des Statistiques, 2005), which define limited risky consumption as the ingestion of at least six standard drinks on a single occasion. This indicator diverges from the definition of female binge drinking by the NIAAA (four or more drinks on a single 
occasion on at least one day in the previous month) in the quantity involved (six drinks in the former as opposed to four in the latter) and in frequency (at least six times a year in the former compared to once in a month in the latter). Our indicator is similar to the one used in surveys conducted by the Australian Institute of Health and Welfare, where a woman's risky drinking behaviour with a shortterm risk of harm is defined as the consumption of five or six standard glasses in one day (Australian Institute of Health and Welfare, 2005). This yields an insight into specific drinking habits in the Kanak community, where intense drinking bouts may be followed by relatively long periods of abstinence.

In addition to women's current age group, which was the stratification variable, three categories of variables were considered for adjustment: early experience of family alcohol-related problems, socioeconomic status and sociodemographic characteristics. Regarding family alcoholrelated problems during childhood, women were asked whether somebody within the household had alcohol problems and who that person(s) was/were. A dichotomous variable was used to code a positive answer, irrespective of the family member mentioned as having the problem.

Socioeconomic status was taken into account with tow variables: educational level and paid work. Educational level was stratified into four categories: none or primary school education, $\mathrm{CAP} / \mathrm{BEP}$ (vocational qualifications at the end of junior high), Baccalaureate, and post-Baccalaureate. We grouped women into two categories depending on whether or not they had passed the Baccalaureate on completing the high school curriculum. In the Kanak community, the social value of this qualification is historically important and remains so today. It is an important advantage in entering the paid work force. Economic status was defined as having or not having any kind of paid work, including temporary or occasional work. In a community where many women work in subsistence agriculture, the availability of personal monetary income is a critical social factor.

Regarding sociodemographic characteristics, four variables were used: place of residence, religion, sociability, and marital status. Places of residence were analysed for the degree of population mixing and the strength of community norms. Three regions were considered with regards to the proportion of Kanaks: Greater Nouméa with a predominantly European population, the rural main island with a majority Kanak population, and the Loyalty Islands with only an indigenous population. In the Islands, patriarchal social structures are still strong and especially unfavourable towards women. 
In contrast, in the city, the burden of gendered social control on Kanak women appears to be weaker. Regarding religion, women who responded positively to the question, "Today, do you have a religion?" were asked to specify: Catholic, Protestant (The two main churches: "Eglise évangélique" and "Eglise Libre"), or other newer Christian churches (Jehovah's Witnesses, Pentecostals, Seventhday Adventists). In rural Kanak society, regular contact with friends and relatives is the dominant form of socialising aside from domestic or productive activities. Such socialising was measured by whether or not regular contact with friends was maintained. Marital status was classified into five categories: married, cohabiting (since long-term cohabitation usually precedes marriage), having a regular sexual partner, separated in the last 12 months, and no regular sexual partner. We did not directly include information on motherhood in this analysis because it is strongly associated with age and marital status, which we do account for in our study.

\section{Statistical analysis}

Binge drinking is taken as the dependent variable using univariate analysis and logistic regression modelling. We studied its association with childhood sexual abuse by adjusting for other determinants of alcohol misuse: age group, family alcohol problems, educational level, paid work, place of residence, religion, sociability and marital status. All variables were included in the regression model simultaneously. Analyses were performed with the Statistical Analysis Software (SAS v9.1, SAS Institute Inc., Mary, NC, USA).

\section{Results}

\section{Characteristics of Kanak women}

The Kanak women in our sample (Table 1) form a young, essentially rural group, with low levels of education, with less than half having an income-producing activity. At the time of the survey, one-third of the women were living as part of a married couple, and a little over a quarter were cohabiting without being married: $17.9 \%$ had a stable partner without cohabitation, some $17.8 \%$ did not have a stable relationship that year, and $4.1 \%$ had separated. Religion was rated as very important or important to most participants with a wide range of religious affiliations. Catholics were the biggest 
group, followed by Protestants, while $8 \%$ of the sample reported that they belonged to a newer Christian church. Almost half the Kanaks stated that, during their childhood, at least one of their parents had alcohol problems (the father in $74 \%$ of cases).

\section{Prevalence of childhood sexual abuse and binge drinking}

Some $11.6 \%$ of Kanak respondents were victims of childhood sexual abuse. These abuses were recurrent in $49 \%$ of cases. The youngest Kanak women reported sexual abuse most frequently (18.8\% in the $18-24$ age group, $11.6 \%$ in the $25-34$ age group, $6.5 \%$ in the $35-44$ age group and $7.3 \%$ in the $45-54$ age group, $\mathrm{p}=0.015$ ). In $63 \%$ of cases, the perpetrator was a close relative; in $33 \%$ of cases, it was a known person; and, in $4 \%$ of cases, the aggressor was a stranger. The perpetrator of childhood sexual abuse was a close relative in $73 \%$ of recurrent cases versus $50 \%$ when sexual abuse occurred only once (data not shown).

Alcohol abstinence in our sample was high (39\%), but more than half of those who drank were heavy drinkers, leading to an overall rate of binge drinking of $34 \%$. This rate was very high in the 18 24 age group and decreased with age. This population either mixed beer or whisky with Coca-Cola or used alcohol and soft drinks alternately during binge drinking sessions.

\section{Factors associated with binge drinking}

Table 2 shows the odds ratios (ORs) for factors associated with adult binge drinking provided by the univariate and multivariate analyses. In the univariate analyses, childhood sexual abuse was associated with an increased likelihood of adult binge drinking ( $\mathrm{OR}=1.84,95 \% \mathrm{CI}: 1.02-3.32)$. Univariate analyses also showed a significant negative gradient in the association between age and binge drinking. Women with paid work reported less binge drinking than those without personal income, but no association was found with education. Binge drinking was more common among women who socialised with friends. Membership in new Christian churches was associated with a lower rate of alcohol abuse compared to the Catholic women. Binge drinking was not different among women who did not report any religious affiliation. Compared to married women, those who separated 
from their partner in the previous 12 months appeared most likely to experience binge drinking, followed by those in a stable non-cohabiting relationship, and those without a steady partner. No significant association was found with alcohol-related family problems during childhood and place of residence in the univariate analysis.

In the multivariate analyses, the association between childhood sexual abuse and adult binge drinking remained stable and even increased slightly $(\mathrm{OR}=1.95,95 \% \mathrm{CI}: 1.02-3.74)$. The age gradient of binge drinking was reduced, from 4 to 3 for the youngest age group. The adjusted oddsratio for paid work decreased and was no longer statistically significant. The adjusted OR for living in the Loyalty Islands was significant $(\mathrm{OR}=2.25,95 \% \mathrm{CI}: 1.08-4.70)$ compared to residence in Greater Nouméa. The significance of an association with religion increased when adjusted (New Christian Churches vs. Catholic: $\mathrm{OR}=0.27,95 \% \mathrm{CI}: 0.10-0.73$ ), while the association with peer sociability remained stable $(\mathrm{OR}=2.09,95 \% \mathrm{CI}: 1.03-4.23)$. Compared to married women, women recently separated $(\mathrm{OR}=6.77,95 \% \mathrm{CI}: 2.09-21.98)$ and those with non-cohabiting partners $(\mathrm{OR}=2.45,95 \%$ CI: 1.25-4.81) were at greater risk of binge drinking.

\section{Discussion}

This study is the first to analyse the contribution of childhood sexual abuse to the likelihood of later binge drinking in an indigenous population in the South Pacific. The results show an independent association between early sexual abuse and binge drinking in adulthood among Kanak women. After controlling for place of residence and factors classically associated with high levels of alcohol consumption in women (age, marital situation, sociability, and religion), childhood sexual abuse is still significantly associated with binge drinking for Kanak women. Social status, assessed by education level and paid employment, does not appear to be associated with binge drinking in this population.

Identifying the consequences of sexual abuse in childhood is especially important in a population where the issue of sexual violence towards women is still not really recognised. Half the Kanak women reporting abuse were abused several times, most often by a close family member, and only $10 \%$ of them reported this violence to the authorities. These facts demonstrate that it is very 
difficult to report acts of sexual abuse in an environment where violence against girls and women is rarely denounced. Nonetheless, awareness is growing. Since the 1990 s, reports of the raping of minors have been rising in New Caledonia, criminal sentences have become more severe, and extenuating circumstances are increasingly rarely recognised (Salomon, 2000b)

The association between early sexual abuse and binge drinking among women in this study is consistent with results of several studies conducted among Native-American women in the United States (Koss, Yuan, Dightman et al., 2003; Robin, Chester, Rasmussen et al., 1997). The strength of the association found in Kanak women in New Caledonia (roughly a factor of 2) is the same as that observed among Native-American women. Nonetheless, the results of different studies must be compared with caution because the measures vary between studies — some are adjusted only for age and parental alcoholism (Robin, Chester, Rasmussen et al., 1997) or for other risk exposures during childhood (Koss, Yuan, Dightman et al., 2003). Another reason for caution is related to the very different prevalence of the phenomena measured in different studies. These may reflect different definitions of childhood sexual abuse and alcohol misuse, reporting bias, or real variations according to country, time period, and community.

For example, in the United States, the rate of childhood sexual abuse reaches $40 \%$ among women of a Southwestern Indian tribe (Robin, Chester, Rasmussen et al., 1997), while it is 12\% among Navajo women (Kunitz, Levy, McCloskey et al., 1998). In the WHO 10-country study of women's health and domestic violence, where sexual abuse was defined as physical sexual contact before age 15, observed rates ranged from $1 \%$ to $20 \%$ (Garcia-Moreno, Jansen, Ellsberg, Heise, \& Watts, 2005). With a very similar definition, the rate of childhood sexual abuse in the Kanak community is around $12 \%$, an intermediate value. Higher rates of childhood sexual abuse in younger women might be attributed both to a recall bias in the eldest and to better reporting in younger generations due to sexual abuse becoming less tolerated and more denounced within the last two decades. A recent increase of childhood sexual abuse, however, cannot be ruled out. In this study, we did not observe any differences between communities (Hamelin \& Salomon, 2007), although research in neighbouring Pacific countries mentions higher frequencies in indigenous populations than in the general population. The mean rate in Australia is $12 \%$, but information specific to communities is not 
available (Australian Bureau of Statistics, 2006). In the Australian Northern Territories, however, an official board of inquiry determined that indigenous girls are much more exposed to sexual abuse than their non-indigenous counterparts (Anderson \& Wild, 2007). According to the WHO definition, 23.5\% of urban women and $28.2 \%$ of rural women in New Zealand were sexually abused before the age of 15 years. In both urban and rural areas, rates were higher among Maori women (Fanslow, Robinson, Crengle et al., 2007).

Studies also use various indicators of substance abuse. US studies focus on alcohol dependence or alcohol abuse, as defined according to DSM criteria, or on illegal drug abuse. The restriction of the present study to binge drinking is due to specific patterns of drinking among Kanak women in this age group, where consumption of cannabis and kava remain occasional and other drugs are still relatively rare. More than a third of Kanak women (34\%) report that they frequently drink large quantities of alcohol (vs. a mean of $23 \%$ in the overall sample). This mode of drinking is also found in other indigenous populations in the Pacific region. In Australia, Aboriginal men and women are abstinent more often than the general population, but $60 \%$ of Aboriginal men and $38 \%$ of Aboriginal women drink nine standard glasses or more when they drink, as opposed to an average 5\% of men and $1 \%$ of women in the general population (Saggers \& Gray, 1998). Similarly, in New Zealand, Pacific Islanders (Maoris and other Polynesian islanders) are more likely to be abstinent but are also more often drunk. In these subgroups, $25 \%$ of female drinkers say they become drunk at least once a week compared with $6 \%$ of drinking women in the general population (Huakau, Asiasiga, Ford et al., 2005). In New Caledonia, at-risk behaviours associated with massive alcohol consumption are now well identified by local health authorities as an important contributor to sexual abuse, unprotected sexual intercourse, physical violence, and traffic accidents (Rouchon, 2005).

Both childhood sexual abuse and alcohol use are likely to be under-reported, and the former is subject to recall bias (Watts \& Zimmerman, 2002; Williams, Siegel, \& Pomeroy, 2000). Underreporting of alcohol consumption is common in studies on this topic, but it is likely to be weakened in a socio-cultural setting where excess drinking is viewed as a normal pattern of use and where reported rates of alcohol consumption are high. In questioning women about childhood sexual abuse, we sought to minimise barriers to disclosure and ease recollection by asking questions about childhood sexual 
abuse after other questions were asked regarding the women's life histories and current conditions. Thus, trust gained during the interview might have facilitated answers to such sensitive questions. These techniques do not, however, completely prevent under-reporting of both the exposure (CSA) and the outcome (binge drinking), which may impact the association observed in this study, as similar analyses have pointed out (Dube, Anda, Felitti et al., 2002).

In Kanak women, the significant association with some sociodemographic variables in the model confirmed the multifactorial character of alcohol abuse. Associations classically observed among other populations of women are seen in diverse forms: the effect of age, the protective role of a relationship, sociability, and religion. The univariate association between economic autonomy and a lower level of alcohol abuse disappeared in the multivariate analysis, principally because of the confounding effect of age; young women, not yet working, drank much more than older women.

Regarding marital status, being in a relationship without cohabiting and recent separation both increased the likelihood of alcohol abuse and suggested situations of instability or transient crisis, which has been shown in many studies (Fleming, 1996; Karlamangla, Zhou, Reuben et al., 2006 ; Kuntsche, Gmel, Knibbe, Kuendig, Bloomfield, Kramer et al., 2006). In the Kanak population, living with either biological or adopted children is associated with a lower rate of binge drinking, but this association is instead explained by marital status. This variable was not included in the final model.

Among religious practices, only affiliation with the "new" Christian churches $(8.2 \%$ of women) is negatively associated with alcohol abuse in a society that has been deeply influenced by historical churches (Catholic and Protestant) since the end of the 19th century. One of the distinctive characteristics of the newer Christian churches, in New Caledonia as elsewhere (Haber \& Jacob, 2007), is the promotion of alcohol abstinence. At the individual level, conversion to newer churches may be interpreted as a way of coping with family problems, leading to distancing from community pressures and then to the endorsement of new behavioural norms, including alcohol abstinence.

In the Kanak community, the predominance of social hierarchy and male authority combined with the hold of official religions is most marked in the Loyalty Islands, where the highest levels of alcohol abuse are observed. Parties where alcohol abuse among women is similar to the excess consumption pattern of men seem to be a release from the weight of social conventions dictating their 
daily lives (Bensa \& Salomon, 2003). This may explain the association observed between sociability between friends and alcohol abuse. Alcohol consumption occurs outdoors ( $42 \%$ of women drink at the beach, in the bush, or in cars) away from men in a society where separation of the sexes is an organisational feature of all productive, domestic, and festive activities.

The cross-sectional design did not allow us to conclude that there are direct causal relations between childhood sexual abuse and adult alcohol consumption. Physical violence, like other early negative experiences, has been shown to contribute to alcohol consumption in adulthood (Afifi, Brownridge, Cox, \& Sareen, 2006). Studies have also demonstrated a graded relationship between the number of adverse childhood experiences and the likelihood of personal alcohol abuse as an adult (Dube, Anda, Felitti et al., 2002). However the present study lacks documentation of childhood physical violence by parents. Actually because of the frequency and socially legitimate character of corporal punishment in raising Kanak children, the researchers have thought that physical violence in childhood was not a distinctive characteristic. Moreover, the pathway between early sexual abuse and alcohol problems is likely to be mediated by intermediate disorders such as post-traumatic stress disorder, depression or general anxiety disorders (Simpson \& Miller, 2002). These mechanisms are difficult to document retrospectively. Moreover the cross-cultural validity of available mental heath scales has not been demonstrated. Consequently, research using more complex models is needed to understand the nature of the correlation between early sexual abuse and women's binge drinking.

\section{Conclusions}

In New Caledonia, the issue of violence towards women became a political and social issue, with the development of the Kanak feminist movement in the 1980s occurring at the same time as the pro-independence movement. The results of this study underline the magnitude of childhood sexual abuse and its long-term consequences on health, especially here in terms of alcohol abuse in the form of binge drinking. Quantifying the phenomenon and identifying its repercussions may support the mobilisation of communities against violence towards women and girls, and the implementation of specific programs. The findings of this study suggest that public health concerns related to childhood sexual abuse are highly relevant to the Kanak community. They also call for improving and giving 
priority to care for children who are victims of violence, to prevent long-term consequences of that abuse, and to develop prevention programs aimed at alcohol-related behaviour in women, taking into account simultaneous individual and collective factors.

\section{References:}

Afifi, T.O., Brownridge, D.A., Cox, B.J., \& Sareen, J. (2006). Physical punishment, childhood abuse and psychiatric disorders. Child Abuse \& Neglect, 30(10), 1093-1103.

Ames, G.M., \& Rebhun, L.A. (1996). Women, alcohol and work: interactions of gender, ethnicity and occupational culture. Social Science and Medicine, 43(11), 1649-1663.

Anderson, P., \& Wild, R. (2007). Ampe Akelyernemane Meke Mekarle. Report of the Northern Territory Board of Inquiry into the Protection of Aboriginal Children from Sexual Abuse (p. 316). Darwin: Nothern Territory Governement.

Australian Bureau of Statistics (2006). Personal Safety Survey 2005 (p. 64). Canberra.

Australian Institute of Health and Welfare (2005). National drug strategy household survey: detailed findings, Drug Statistics Series (p. 130). Canberra: The Australian Government Department of Health and Ageing.

Beauvais, F. (1998). American Indians and Alcohol. Alcohol Health and Research World, 22(4), $253-$ 259.

Bensa, A., \& Freyss, J. (1994). La société Kanak est-elle soluble dans l'argent? Terrain, 23, 11-26.

Bensa, A., \& Salomon, C. (2003). Nouvelle-Calédonie. Les Kanaks face à l'appareil judiciaire (p. 83). Paris: Mission de Recherche Droit et Justice.

Bensley, L.S., Eenwyk, J.V., \& Simmons, K.W. (2000). Self-reported childhood sexual and physical abuse and adult HIV-risk behaviors and heavy drinking. American Journal of Preventive Medicine, 18(2), 151-158.

Brady, M., \& Palmer, K. (1984). Alcohol in the Outback Darwin: Australian National University, North Australia Research Unit.

Brady, M. (2000). Alcohol policy issues for indigenous peaple in the United States, Canada, Australia and New Zealand. Contemporary drug problems, 27, 435-509. 
Caetano, R.C., Clark, C.L., \& Tam, T. (1998). Alcohol consumption among racial/ethnic minorities. Theory and Research. Alcohol Health and Research World, 22(4), 233-241.

Collins, R.L., \& McNair, L.D. (2002). Minority women and alcohol use. Alcohol Research and Health, 26(4), 251-256.

Day, N.L., \& Homish, G. (2002). The epidemiology of alcohol use, abuse and dependance. In T. Tsuang Ming, \& M. Tohen (Eds.), Textbook in Psychiatric Epidemiology. Second Edition (pp. 459-477). New York: Wiley-Liss.

Direction de la Recherche des Etudes de l'Evaluation et des Statistiques (2005). Le risque d'alcoolisation excessive : des écarts entre les déclarations des patients et l'avis des médecins. Etudes et résultats, 405, 1-12.

Direction des Affaires Sanitaires et Sociales (2003). Situation sanitaire en Nouvelle-Calédonie (p. 28). Nouméa: DASS

Djama, M. (1999). Transformations agraires et systèmes ruraux mélanésiens en Grande-Terre de Nouvelle-Calédonie. Journal d'Agriculture Traditionnelle et de Botanique Appliquée, 41(1), 201-224

Dube, S., Anda, R., Felitti, V., Edwards, V., \& Croft, J. (2002). Adverse childhood experiences and personal alcohol abuse as an adult. Addictive behavior, 27(5), 713-725.

Fanslow, J.F., Robinson, E.M., Crengle, S., \& Perese, L. (2007). Prevalence of child sexual abuse reported by a cross-sectional sample of New Zealand women. Child Abuse \& Neglect, 31(9), $935-945$

Fleming, J. (1996). The epidemiology of alcohol use in Australian women: finding from a national survey of women's drinking. Addiction, 91(9), 1325-1334.

Garcia-Moreno, C., Jansen, H.A.F.M., Ellsberg, M., Heise, L., \& Watts, C. (2005). WHO multicountry study on women's health and domestic violence against women: Initial results on prevalence, health outcomes and women's responses. Geneva: Worl Health Organisation.

Guillonneau, M., \& Kensey, A. (1999). Les détenus outre-mer Edition Cahiers de démographique pénitentiaire. Paris: Ministère de la justice. 
Haber, J.R., \& Jacob, T. (2007). Alcoholism Risk Moderation by a Socio-religious Dimension. Journal of Studies on Alcohol and Drugs, 66(6), 912-922.

Hamelin, C. (2000). Les gens de Nouméa. Mutations et permanences en milieu urbain. In A. Bensa, \& I. Leblic (Eds.), En pays kanak. Ethnologie, linguistique, histoire, archéologie en NouvelleCalédonie (pp. 339-354). Paris: Editions de la Maison des sciences de l'homme.

Hamelin, C., \& Wittersheim, E. (2002). Au delà de la tradition. In C. Hamelin, \& E. Wittersheim (Eds.), La tradition et l'état : églises, pouvoirs et politiques culturelles dans le Pacifique (pp. 11-23). Paris: L'Harmattan.

Hamelin, C., \& Salomon, C. (2007). Violences et Familles en Nouvelle-Calédonie. Perspectives ethnographique et statistique. In N. Chetcuti, \& M. Jaspard (Eds.), Violence envers les femmes - Trois pas en avant deux pas en arrière (pp. 257-274). Paris: L'harmattan.

Huakau, J., Asiasiga, L., Ford, M., Pledger, M., Casswell, S., Suaalii-Sauni, T., \& Lima, I. (2005). New Zealand Pacific people's drinking style: too much or nothing at all ? The New Zealand Medical Journal, 118(1216), 1-10.

Institut de Recherche et Documentation en Economie de la Santé (2005). Questions d'économie de la santé. Bulletin d'information en économie de la santé, 97, 1-8.

Institut Louis Harris (2003). Etude sur les comportements vis-à-vis de l'alcool en Nouvelle-Calédonie (p. 68).

Institut Territorial de la Statistique et des Etudes Economiques (2001). Bilan démographique au seuil des années 2000. La population calédonienne au seuil des années 2000., Notes et Documents $N^{\circ} 82$ (p. 124). Nouméa: ITSEE.

Jasinski, J.L., Williams, L.M., \& Siegel, J. (2000). Childhood physical and sexual abuse as risk factors for heavy drinking among African-American women: a prospective study. Child Abuse \& Neglect, 24(8), 1061-1071.

Karlamangla, A., Zhou, K., Reuben, D., Greendale, G., \& Moor, A. (2006). Longitudinal trajectories of heavy drinking in adults in the United States of America. Addiction, 101(1), 91-99. 
Koss, M.P., Yuan, N.P., Dightman, D., Prince, R.J., Polacca, M., Sanderson, B., \& Goldman, D. (2003). Adverse Childhood Exposures and Alcohol Dependance Among Seven Native American Tribes. American Journal of Preventive Medicine, 25(3), 238-244.

Kunitz, S.J., Levy, J.E., McCloskey, J., \& Gabriel, K.R. (1998). Alcohol dependence and domestic violence as sequelae of abuse and conduct disorder in childhood. Child Abuse \& Neglect, 22(11), 1079-1091

Kunitz, S.J., Gabriel, K.R., Levy, J.E., Henderson, E., Lampert, K., McCloskey, J., Quintero, G., Russel, S., \& Vince, A. (1999). Risk factors for conduct disorder among Navajo Indian men and women. Social Psychiatry and Psychiatric Epidemiology, 34, 180-189.

Kunitz, S.J. (2006). Life-Course Observations of Alcohol Use among Navajo Indians: Natural History or Careers? Medical Anthropology Quarterly, 20(3), 279-296.

Kuntsche, E., Rehm, J., \& Gmel, G. (2004). Characteristics of binge drinkers in Europe. Social Science and Medicine, 59(1), 113-127.

Kuntsche, S., Gmel, G., Knibbe, R.A., Kuendig, H., Bloomfield, K., Kramer, S., \& Grittner, U. (2006). Gender and cultural differences in the association between family roles, social stratification, and alcohol use: a european cross-cultural analysis. Alcohol and Alcoholism, 41(Supplement 1), 37-45.

Langeland, W., \& Hartgers, C. (1998). Child sexual and physical abuse and alcoholism: a review. Jounal of the Studies on Alcohol, 59(3), 336-348.

Libby, A.M., Orton, H.D., Novins, D.K., Spicer, P., Buchwald, D., Beals, J., \& Manson, S.M. (2004). Childhood Physical and Sexual Abuse and Subsequent Alcohol and Drug Use Disorders in Two American-Indian Tribes. Journal of Studies on Alcohol, 65(1), 74-83.

May, P., \& Gossage, J. (2001). The epidemiology of alcohol consumption among american indians living on four reservations and in nearby border towns. Drug and Alcohol Dependance, 63(Supplement 1), 100.

Merle, I. (1995). Experiences coloniales : La Nouvelle-Calédonie, 1853-1920 Paris: Belin 
Naepels, M. (2000). Partir à Nouméa. Remarques sur les migrants originaires de la région ajië. In A. Bensa, \& I. Leblic (Eds.), En pays kanak. Ethnologie, linguistique, histoire, archéologie de la Nouvelle-Calédonie (pp. 355-366). Paris: Éditions de la Maison des Sciences de 1'Homme.

Naepels, M., \& Salomon, C. (2007). Terrains et destins de Maurice Leenhardt Paris: EHESS.

Robin, W.R., Chester, B., Rasmussen, J.K., Jaranson, J.M., \& Goldman, D. (1997). Prevalence, characteristics and impact of childhood seuxal abuse in a southwestern american indian tribe. Child Abuse \& Neglect, 21(8), 769-787.

Rouchon, B. (2005). Repères de consommation d'alcool en Nouvelle-Calédonie. Bulletin Médical Calédonien et Polynésien, 43, 4.

Roy, B. (2005). Alcool en milieu autochtone et marqueurs identitaires meurtriers. Drogues, Santé et Société, 4(1), 85-128.

Saggers, S., \& Gray, G. (1998). Dealing with alcohol: indigenous usage in Australia, New Zealand and Canada. Melbourne: Cambridge University Press.

Salomon, C. (1998). La personne et le genre au centre nord de la Grande Terre (Nouvelle-Calédonie). Gradhiva, 23, 81-100.

Salomon, C. (2000a). Hommes et femmes. Harmonie d'ensemble ou antagonisme sourd. In A. Bensa, \& I. Leblic (Eds.), En pays Kanak (pp. 331-338). Paris: Maison des sciences de l'homme.

Salomon, C. (2000b). Les femmes kanakes face aux violences sexuelles et domestiques : le tournant judiciaire des années 1990. Le journal des anthropologues, 82, 287-307.

Salomon, C., \& Hamelin, C. (2008). Why Are Kanak Women More Vulnerable to HIV than Others, Ethnographical and Statistical insights. In L. Butt, \& R. Eves (Eds.), Making sense of AIDS. Culture Power and Sexuality in Melanesia (pp. 80-96). Honolulu: University of Hawai'i Press.

Shore, J.H., \& Spicer, P. (2004). A model for alcohol-mediated violence in an Australian Aboriginal community. Social Science and Medicine, 58(12), 2509-2521.

Simpson, T., \& Miller, W. (2002). Concomitance between childhood sexual and physical abuse and substance use problems: a review. Clinical Psychology Review, 22(1), 27-77. 
Stanley, J., Kovacs, K., Tomison, A., \& Cripps, K. (2002). Child Abuse and Family Violence in Aboriginal Communities - Exploring Child Sexual Abuse in Wester Australia (p. 89) Melbourne: National Child Protection Clearinghouse - Australian Institue of Family Studies.

Watts, C., Heise, L., Ellsberg, M., \& Garcia-Moreno, C. (2001). Putting women first: Ethical and safety recommandations for research on domestic violence against women (p. 31). Geneva: World Health Organisation.

Watts, C., \& Zimmerman, C. (2002). Violence against women: global scope and magnitude. The Lancet, 359(9313), 1232-1237.

Williams, L.M., Siegel, J.A., \& Pomeroy, J.J. (2000). Validity of women's self-reports of documented child sexual abuse. In A. Stone, \& J.S. Turkkan (Eds.), The science of self-report: Implications for research and practice (pp. 211-226). Mahwah: Lawrence Erlbaum. 